\title{
DOCUMENTARY FRAGMENTS, POP-POLITICS, AND FASCISM
}

\author{
Ronald E. Day \\ Department of Information and Library Science \\ Indiana University at Bloomington \\ roday@indiana.edu
}

\begin{abstract}
This article addresses the role of social media fragments in the return of fascist politics It argues that beside or contrary to a conscious collective intelligence emerging through the internet, a collective unconscious has seized the political space, delegitimatizing modern institutions of documentary truth based on evidence, method, and the institutional construction of facts.
\end{abstract}

Keywords: Internet. Social mídia. Facism. Trump.

\section{FRAGMENTOS DOCUMENTAIS, POP-POLÍTICA E FASCISMO.}

\section{Resumo}

Neste artigo se discute o papel de parte da mídia social no retorno de uma política fascista. Argumentar-se que ao lado ou ao contrário de uma consciente inteligência coletiva emergindo através da Internet, há uma inconsciência coletiva ocupando a esfera política, deslegitimando as instituições modernas dos documentos verdadeiros baseados em evidências, e a construção institucional dos fatos.

Palavras-chave: Internet. Mídias sociais. Fascismo. Trump.

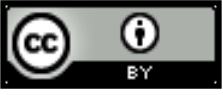

Esta obra está licenciada sob uma Licença Creative Commons Attribution 3.0.

LOGEION: Filosofia da informação, Rio de Janeiro, v. 3 n. 2, p. 10-17, mar./ ago. 2017. 
I'd like to discuss what I'll call pop-politics, its enablement by documentary fragmentation, and the rise of fascism in the United States and Western Europe, not the least through the devaluation and destruction of a long tradition of institutions of documentary evidence. I'd particularly like to focus on the rhetorical affordances that online media have brought to politics, not only in terms of the documentary forms of that media, but also in terms of the context of our ubiquitous mediation by those forms. It is not only the form of these documentary media that are important, but their ubiquity. Further, both these factors are important during a moment in history when politically right 'revolutionary' forces once again make use of long simmering prejudices and resentments in order to displace rightful anger in wealth concentration by the wealthiest people. This moment in the United States and in Western Europe is not unlike that when Walter Benjamin wrote his "Work of Art in the Age of Mechanical Reproduction" in 1935, ending it with:

"Fiat ars - pereat mundus", says Fascism, and, as Marinetti admits, expects war to supply the artistic gratification of a sense perception that has been changed by technology. This is evidently the consummation of "l'art pour l'art." Mankind, which in Homer's time was an object of contemplation for the Olympian gods, now is one for itself. Its self-alienation has reached such a degree that it can experience its own destruction as an aesthetic pleasure of the first order. This is the situation of politics which Fascism is rendering aesthetic. Communism responds by politicizing art. (BENJAMIN, 1968)

The poetic art of Italian Futurist rapid fire words, imitating the machine gun, is today found in the technologies of Twitter feeds and 24-hour news. Not unreasonably hooked on the frenzy of half-documentary, half-communicational forms of social media that under President Trump convert rumor, prejudice, and media spectacle into instantaneous policy and governmental force, today we exist somewhere between the simulacra release of pure signifiers and those institutions that once grounded signifiers within the largely hidden weights of argument, evidence, experiment, and peer review. If the term 'postmodernity' had any meaning, it is this: the actualization of simulacrum without regard to modernist institutions of producing facts and truth. The problem of a 'post-fact' politics (science, knowledge, etc.) is not only in relation to facts, of course, but the bigger problem of the lack of trust in the institutions, methods, and manners of fact production and verification that gave us trusted documents and gave trust to documents as printed (in paper or otherwise) assertions. Here are the foundations of modernity in all areas of technical production, knowledge, and justice. Its destruction in the name of a more instantaneous truth, which also makes use of immigrant and minority peoples as scapegoats in the name of the defense of an oppressed 
working class and a claimed national authenticity and national and cultural superiority, earns this politics the moniker of 'fascism,' as it exactly replicates that event in Europe in the early $20^{\text {th }}$ century. Fascism is itself 'post-modern,' though the post-modern is, of course, not necessarily fascist.

In his An Inquiry into Modes of Existence, Bruno Latour has written a key observation on skepticism regarding institutional mediations for truth production. It comes in the form of an anecdote, which tells of a climate skeptic asking a climate researcher why people should believe the latter in regard to the truth of anthropocentric theories about climate change. Instead of appealing to numbers, models, or other means of evidence, the climate researcher responds, "'If people don't trust the institution of science, we're in serious trouble" (LATOUR, 2013).

Latour's observation gets to the heart of this article. The fragmentation of documentary forms by new media and their role in politics today brings us back to Benjamin's observations during the rise of fascism in Europe (when this fragmentation occurred through film, radio, and nascent television broadcasts). I want to highlight in this article how these documentary fragments have left the documentary institutions that once gave them grounding as fact. The divorce of documents from institutional grounds of verification and truth is not just an issue of documentary fragmentation per se, but of the political erosion of trust in modernist institutions. Arguably, though, this erosion has been accelerated and intensified by the use of documentary fragments to obfuscate and lie.

The concern that signifiers be grounded in institutions and institutional practices in order for factual truth to occur is nothing new, of course The father of European documentation, Paul Otlet, was concerned with the relation of signification to institutions of fact creation, though his notion of fact was ultimately grounded in a positivist reductionism that ended with library reference documentation itself. On the other hand, from a perspective of being rightfully critical of such a reductionism, Frohmann has written,

Otlet's grafting of an 'order of things' onto his documentation to stabilize a privileged order of signs of facts, or 'items of information', is a kind of metaphysical hedge against iterability, 'différance', and the trace, on which Derrida spent much time and energy in deconstructing. But iterability poses a fatal problem for this privileged order. If a sign is iterable, if it can be divorced from one chain of signs and inserted in another, it bears the mark of the trace and is structured by 'différance'. Its meaning is not exhausted in reaching out and embracing its referent. There will always be, as an essential part of the sign, traces of the possibilities of other signs, hence traces of other orders. The sign's ultimate 
space is not a position in a stable structure yet to come, but the whole space of possibility of relations between signs. The trace-structure of the sign thus contaminates any privileged order of signs. Otlet's dream of severing signs of facts from other signs - such that they reveal, without remainder, the facts themselves and just the facts in their full presence - is plagued by the nightmare of the freedom of authorial subjectivity, which Otlet sees as a 'debasement': an endless play of signs of facts slipping from one order to another, ad infinitum - a play of signs without any transcendent, stabilizing foundation. (FROHMANN, 2007)

There are two elements in this quote from Frohmann that I would like to highlight here: first, there is the issue of "the play of signs of facts slipping from one order to another, ad infinitum," and second, "the whole space of possibility of relations between signs."

President Donald Trump's Twitter feeds during his presidency today and the role that they played during his (first) presidential campaign ( - one month into his presidency he began his second, 2020 campaign -) give good credence to Marinetti's proclamation of "Fiat ars - pereat mundus" (let art be created-let the world perish), based on the detachment of the signifier and signified as relations of evidence or proof. 'Signifieds' as concepts of fact disappear when the institutions, techniques, and methods of argument and verification are destroyed. However, because of our traditions of knowledge publication, particularly when issued by authoritative institutions, we often assume that there are reliable institutions and traditions behind such assertions. We assume with 'information' that there is at least the possibility for truth in such assertions. And because of this, such information is paid attention to and circulates, whether it can ever become knowledge or not.

Otlet's concerns that signification be institutionally grounded was a rightful concern, though his theoretical arguments ended up reasserting the domain of signification without facts through a documentary or evidentiary reductionism that ends in the a priori categories of traditional library pre-coordinate vocabularies. Otlet's works demonstrate a reactionary attitude toward iteration out of fear that iteration itself is always ungrounded if it isn't, totally and finally, inscribed. Ironically, the priority of inscription for iteration is, here, forgotten and obliterated.

In contrast to Otlet's documentary institutions and techniques, internet institutions and techniques are primarily interested in serving user needs. User information needs are not necessarily related to truth, however, but can involve opinion and all types of expressions and meaning generation beyond those of knowledge institutions, methods, and their traditions.

In some quarters until recently, there was much celebration given to the demise of 
traditional documentation, its techniques, and even its institutions (such as libraries and published encyclopedias). In the place of such institutionalized information was supposedly 'the people,' who would, either through their own authority or through the 'marketplace of ideas,' give us facts. And though this has come about in some ways, in other ways it has still required editorial control (e.g., Wikipedia) or the insertion of old media and its verification procedures (such as fact checking in journalism) or the use of old information literacy norms.

When is information not fact, even though it is asserted and published in a documentary form? The obvious answer is when it lacks the institutional means to be a fact. But this institutional means is often assumed, and its absence is often not evident in the very rhetorical and sociological appearance of information.

Let us return to the Trumpian Twitter feeds and the 'post-fact' world. With Twitter and other social media, we are dealing with documentary fragments. Why are Twitter 'tweets' documentary fragments? Most apparently, because they are small 'chunks' of information. But more importantly, because the very thing that made this information documentary-that is evidence - namely argument, verification, authoritative consensus, etc.-is missing. But, since documentation has been so long associated with expressions made in the public, and even with assertion more generally (indeed, since Plato's dialogues, where the dialogue or conversation must have some end in 'truth'), we often assume, as a matter of habit and tradition, that there must be some possibility of truth associated what is asserted.

If truth is not to be generated by documentary evidence, however, then where does it come from? The assertion, and particularly the published assertion, is a proposition that demands a form of explanation to accompany it. Here, we must look to two modernist phenomena that answer this demand: contagion and ideology.

Contagion is part of the social bond that humans have. We share language, we share empirical worlds that we act upon, and we share commonalities of bodily construction. We are interested in common things, we communicate through common ideas (or at least symbols), and we do so in at least physically common ways, using shared cultural forms and through shared social norms.

Arguably, in the midst of the ubiquitous use of personal computers we need to share bonds through symbolic means in order to replace the physical bonds that were once physically shared. Personal computers symbolically connect us through great distances, but they also can take away 
from the greater time that we once spent physically together.

How do they connect us to one another? They do so through shared ideas. Ideas are assemblages of symbols and their references and senses. As such, they afford potential and actualized actions.

Communicative 'memes' are small symbolic elements that carry with them ideas, constellations of ideas (ideologies), and their references and sense. They are what Serres called quasi-objects, which can manifest in what I called "informational objects" (Day, 2001). Informational objects give information about their referents, but they also trace the ideological domains that they issue from or belong to.

Trump-tweets reference both real and imagined objects and events, but their greater function is purely performative: to create a community of fans. This performative function is even greater when the referential expressions are completely absurd or have malicious intent, for the primary purpose of the Trump memes is not to express truth, but rather, to support a sociological body of belief, which itself gives these memes their meaning and value. Such beliefs are not just constructed through the memes, of course, but these memes carry with them references and senses of already established concepts and actions that lie in a collective ideological unconscioussometimes a 'surface' historical unconscious lying in current economic conditions, and sometimes a 'deep' historical unconscious, which lies in nationalist myths and sexist and racist legacies.

'Collective intelligence' in regard to the Internet was once seen as a very positive phenomenon, leading to greater and better knowledge. It was thought in terms of conscious knowledge. It was believed that 'the crowd' was intellectually superior to 'the mass' and inclined toward democratic participation, and so it was believed that through the internet fascism was past. It isn't that any media is intrinsically inclined toward any political formation, however. Nor is it that ideology has disappeared, as either a broad social psychology or as one also with political functions. The past, as well, hasn't remained buried, but reappears as the collective vectors through which the 'memes' or tropes of social networking pass one to another and cohere the whole. If collective intelligence on the internet were just conscious acts of fact assertion and contestation, then we wouldn't have much of the Internet today, which lies rather in taste and social bonding. Collective intelligence on the Internet includes the collective, ideological, unconscious, which is not necessarily 'intelligent' in any conscious, much less methodological, sense at all.

We live in highly mediated worlds of what Patrick Wilson called "second hand knowledge," 
which largely lie outside of traditional documentary and bureaucratic worlds of truth production. As always in so much of our social lives, we live less in a collective conscious intelligence than a collective unconscious, except now, ubiquitously mediated by second hand knowledge, the larger political unconscious plays a greater role in mediating our everyday information gathering and judging activities.

The truly revolutionary task today still lies not in placing 'the people' above institutions of truth, but rather, to bring to people these institutions through libraries and education and to make these institutions still more rigorous and less prone to the controlling hands of concentrated wealth. Shockingly, this task still remains largely unfulfilled in the United States. The unfulfilled right to knowledge and truth haunts us, increasingly in the political purging of the very institutions that we depend on for these.

LOGEION: Filosofia da informação, Rio de Janeiro, v. 3 n. 2, p. 10-17, mar./ ago. 2017. 


\section{Referências}

BENJAMIN, W. The work of art in the age of mechanical reproduction. In: ARENDT, H. (Ed.). Illuminations. New York:

Schocken, 1968. p. 217-251.

DAY, R. E. The modern invention of information: discourse, history, and power. Carbondale: Southern Illinois University Press, 2001.

FROHMANN, B. The role of facts in Paul Otlet's modernist project of documentation. In: RAYWARD, W. B. (Ed.), European modernism and the information society: informing the present, understanding the past. Burlington, VT: Ashgate, 2007. p. 7588.

\section{LATOUR, B. An inquiry into modes of} existence: an anthropology of the moderns. Massachusetts: Harvard University Press, 2013.
Benjamin, W. (1968). The work of art in the age of mechanical reproduction (H. Zohn, Trans.). In H. Arendt (Ed.), Illuminations (pp. 217-251). New York: Schocken.

Day, R. E. (2001). The modern invention of information discourse, history, and power

Frohmann, B. (2007). The role of facts in Paul Otlet's modernist project of documentation. In W. B. Rayward (Ed.), European modernism and the information society: Informing the present, understanding the past (pp. 75-88).

Burlington, VT: Ashgate.

Latour, B. (2013). An inquiry into modes of existence : an anthropology of the moderns.

\section{References}

LOGEION: Filosofia da informação, Rio de Janeiro, v. 3 n. 2, p. 10-17, mar./ ago. 2017. 